\title{
Cellular Physiology

\section{Janus Kinase 3 is Expressed in Erythrocytes, Phosphorylated Upon Energy Depletion and Involved in the Regulation of Suicidal Erythrocyte Death}

\author{
Shefalee K. Bhavsar, Shuchen Gu, Diwakar Bobbala and Florian \\ Lang
}

Department of Physiology, University of Tübingen, Tübingen

\section{Key Words}

Cell volume $\cdot$ Annexin • Eryptosis • Janus kinase 3 • Phosphatidylserine

\begin{abstract}
Janus kinase 3 , a tyrosine kinase expressed in haematopoetic tissues, plays a decisive role in Tlymphocyte survival. JAK3 deficiency leads to (Severe) Combined Immunodeficiency (SCID) resulting from enhanced lymphocyte apoptosis. JAK3 is activated by phosphorylation. Nothing is known about expression of JAK3 in erythrocytes, which may undergo apoptosis-like cell death (eryptosis) characterized by cell membrane scrambling with phosphatidylserine exposure and cell shrinkage. Triggers of eryptosis include energy depletion. The present study utilized immunohistochemistry and confocal microscopy to test for JAK3 expression and phosphorylation, and FACS analysis to determine phosphatidylserine exposure (annexin binding) and cell volume (forward scatter). As a result, JAK3 was expressed in erythrocytes and phosphorylated following $24 \mathrm{~h}$ and $48 \mathrm{~h}$ glucose depletion. Forward scatter was slightly but significantly smaller in erythrocytes from JAK3-deficient mice $\left(j a k 3^{-/)}\right.$than
\end{abstract}

\section{KARGER}

Fax +41613061234

E-Mail karger@karger.ch

www.karger.com
(C) 2011 S. Karger AG, Basel

$1015-8987 / 11 / 0275-0547 \$ 38.00 / 0$

Accessible online at:

www.karger.com/cpb in erythrocytes from wild type mice $\left(j a k 3^{+/+}\right)$. Annexin $\mathrm{V}$ binding was similarly low in both genotypes. The JAK3 inhibitors WHI-P131/JANEX-1 (4-(4'Hydroxyphenyl)amino-6,7-dimethoxyquinazoline, $156 \mu \mathrm{M})$ and WHI-P154 (4-[(3'-Bromo-4'-hydro-

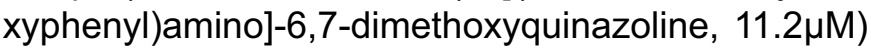
did not significantly modify annexin $\mathrm{V}$ binding or forward scatter. Glucose depletion increased annexin $\mathrm{V}$ binding, an effect significantly blunted in jak $3^{--}$ erythrocytes and in the presence of the JAK3 inhibitors. The observations disclose a completely novel role of Janus kinase 3 , i.e. the triggering of cell membrane scrambling in energy depleted erythrocytes.

Copyright () 2011 S. Karger AG, Basel

\section{Introduction}

The Janus kinase 3 (JAK3) is a nonreceptor tyrosine kinase involved in the signalling of cytokine receptors of hematopoietic cells [1-5]. In lymphocytes and tumor cells JAK3 participates in the stimulation of cell proliferation and confers protection against apoptosis [6-8]. Along those lines, JAK 3 inhibitors have been shown to foster apoptosis of those cells $[9,10]$. In contrast, expression levels of

Prof. Dr. Florian Lang

Physiologisches Institut, der Universität Tübingen

Gmelinstr. 5, 72076 Tübingen (Germany)

Tel. +497071 29 72194, Fax +497071 295618

E-Mail florian.lang@uni-tuebingen.de 
pro-apoptotic proteins is decreased and the survival is increased in JAK3-deficient $\left(j a k 3^{--}\right)$dendritic cells [11]. In those cells JAK3 thus fosters suicidal cell death.

Similar to nucleated cells, erythrocytes may undergo suicidal death or eryptosis $[12,13]$. Similar to apoptosis of nucleated cells eryptosis is paralleled by cell shrinkage, cell membrane blebbing and cell membrane scrambling resulting in exposure of phosphatidylserine at the erythrocyte surface [12-14]. Eryptosis is triggered by anemia-causing xenobiotics and endogeneous mediators $[12,15-21]$ and accelerated eryptosis has been observed in several clinical disorders [12, 13], including iron deficiency [22], phosphate depletion [23], hemolytic uremic syndrome [24], sepsis [25], malaria [13, 26-29] or Wilson's disease [30]. Eryptosis is further triggered by energy depletion following glucose withdrawal [31] and is inhibited by the energy sensing kinase AMPK [32].

Whether JAK 3 is expressed in erythrocytes and whether the kinase plays a role in the regulation of erythrocyte survival has never been tested. The present study thus explored, whether JAK3 is expressed in erythrocytes and plays a role in the regulation of suicidal erythrocyte death upon energy depletion.

\section{Materials and Methods}

\section{Human erythrocytes}

Leukocyte-depleted erythrocytes from concentrates provided by the blood bank of the University of Tübingen were used. In erythrocyte concentrates leukocytes are depleted by a factor of at least 2000 in respect of whole blood [33]. The volunteers providing erythrocytes gave informed consent. The study has been approved by the Ethical commission of the University of Tübingen.

\section{Mice}

Experiments were performed in 6-12 week old male and female JAK3-deficient mice $\left(j a k 3^{-/}\right)$and corresponding wild type mice $\left(j a k 3^{+/+}\right)$purchased from Charles River Laboratories, Sulzfeld, Germany. The $j a k 3^{-/}$mice have been described previously [34]. All animal experiments were conducted according to the guidelines of the American Physiological Society as well as the German law for the welfare of animals and were approved by local authorities.

Blood chemistry, blood count and isolation of murine erythrocytes

For all experiments except for the blood count heparin blood was retrieved from the mice. The plasma concentrations of erythropoietin were determined using an immunoassay kit according to the manufacturer's instructions (R\&D systems, Wiesbaden, Germany). For blood count EDTA blood was analyzed using an electronic hematology particle counter (scil
Vet abc, Weinheim, Germany). Murine erythrocytes were isolated by washing two times with Ringer solution containing (in mM) $125 \mathrm{NaCl}, 5 \mathrm{KCl}, 1 \mathrm{MgSO}_{4}, 32 \mathrm{HEPES} / \mathrm{NaOH}$ (pH 7.4), 5 glucose, $1 \mathrm{CaCl}_{2}$.

\section{Western blotting}

To examine the expression of JAK3 in human or murine erythrocytes $150 \mu$ l erythrocyte pellet were lysed in $50 \mathrm{ml}$ of 20 $\mathrm{mM}$ N-2-hydroxyethylpiperazine-N-2-ethanesulfonic acid (HEPES)/ $\mathrm{NaOH}(\mathrm{pH} \mathrm{7.4)}$. Ghost membranes were pelleted $\left(15,000 \mathrm{x}\right.$ g for $20 \mathrm{~min}$ at $\left.4^{\circ} \mathrm{C}\right)$ and lysed in $200 \mu 1$ lysis buffer $(50$ $\mathrm{mM}$ Tris-HCl, pH 7.5, $150 \mathrm{mM} \mathrm{NaCl}, 1 \%$ Triton X-100, 0.5\% SDS, $1 \mathrm{mM} \mathrm{NaF}, 1 \mathrm{mM} \mathrm{Na} \mathrm{VO}_{4}, 0.4 \%$ B-mercaptoethanol) containing protease inhibitor cocktail (Sigma). For determination of the total erythrocyte protein, $300 \mu$ l erythrocyte from each sample were lysed in $300 \mu 1$ ice-cold lysis buffer. In all cases 50 $\mu \mathrm{g}$ of protein were solubilized in Laemmli sample buffer at $95^{\circ} \mathrm{C}$ for $5 \mathrm{~min}$ and resolved by $10 \%$ SDS-PAGE. For immunoblotting proteins were electro-transferred onto a PVDF membrane and blocked with 5\% nonfat milk in TBS- $0.10 \%$ Tween 20 (TBST) at room temperature for $1 \mathrm{~h}$. Then, the membrane was incubated with affinity purified rabbit anti-JAK3 antibody $(1: 1000 ; 62 \mathrm{kDa}$, Cell Signaling, Germany), at $4^{\circ} \mathrm{C}$ overnight. After washing 3 times with TBST (10 min each) the blots were incubated with horseradish peroxidase conjugated secondary anti-rabbit antibody (1:2000; Cell Signaling) for $1 \mathrm{~h}$ at room temperature. After washing antibody binding was detected with the ECL detection reagent (Amersham, Freiburg, Germany). Antibodybinding was quantified with Quantity One Software (Biorad, Germany).

\section{Immunoprecipitation and Western blotting}

To detect phospho-tyrosine Jak3 $1500 \mu \mathrm{g}$ of total protein from erythrocytes were immunoprecipitated with $6 \mu \mathrm{g}(2 \mu \mathrm{g} /$ $500 \mu \mathrm{g}$ total protein) of p-Tyr (PY-20) (sc-508; Santa Cruz Biotech) using the Dynabeads Protein G immunoprecipitation kit from Invitrogen following the manufacturer's protocol. Then the subsequent western blotting with affinity purified rabbit anti-JAK3 antibody (1:1000; 62 kDa, Cell Signaling, Germany) was performed. The total JAK3 protein also detected in same samples by western blotting with JAK3 antibody

\section{Confocal microscopy and immunofluorescence}

For the detection of JAK3 erythrocytes were resuspended in PBS at $5 \times 10^{7}$ cells $/ \mathrm{ml}$, and $20 \mu 1$ were smeared onto a glass slide. After air drying for $30 \mathrm{~min}$ and fixation with methanol for 2 min the slide was rinsed 4 times over 10 min with PBS. Then, the slide was blocked with 10\% normal goat serum (Invitrogen, Paisley, UK) for $10 \mathrm{~min}$ and again rinsed 3 times with PBS for 5 min each. After incubation with rabbit anti-JAK3 antibody (1:200, Cell signaling) or rabbit anti-phospho- JAK3 (tyr 980) (1:50, Santa Cruz Biotech), diluted in PBS at $4{ }^{\circ} \mathrm{C}$ overnight, the slide was again rinsed 3 times with PBS for 5 min each. Subsequently, the slide was incubated with FITC-conjugated goat anti-rabbit antibody (1:500, Invitrogen), diluted in PBS for $1.5 \mathrm{~h}$ at room temperature. For control, the slide was incubated only with FITC-conjugated goat anti-rabbit antibody. Then, the slide was rinsed 3 times with PBS for 10 min each and

Bhavsar/Gu/Bobbala/Lang 
Fig. 1. Expression and phosphorylation of JAK3 in human erythrocytes. A. Original Western blots demonstrating the expression of total JAK3 protein in total lysate and in membrane preparations of erythrocytes. B. Confocal microscopy of FITCdependent fluorescence of human erythrocytes stained with a primary anti-JAK3 antibody and a secondary FITC-conjugated anti rabbit antibody. C. Original Western blot of tyrosine phosphorylated JAK3 protein in erythrocytes upon incubation in Ringer and following $24 \mathrm{~h}$ and $48 \mathrm{~h}$ energy depletion (by incubation in glucose-free Ringer) determined by immunoprecipitation of erythrocyte total cell lysate with phospho-tyrosine antibody followed by western blotting with JAK3 an-

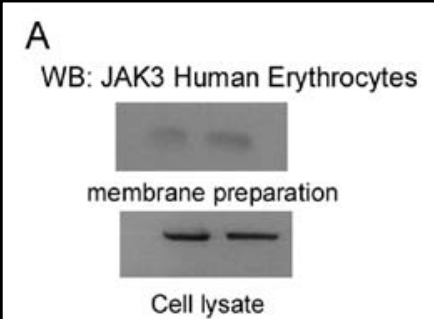

C

Energy depletion 24h Total lysate

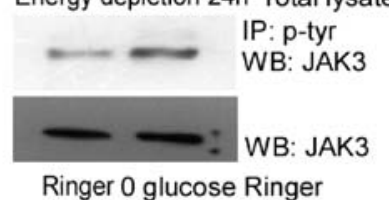

Energy depletion $48 \mathrm{~h}$

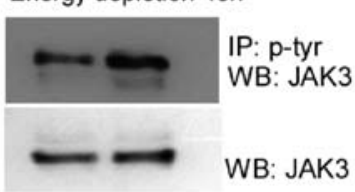

Ringer 0 glucose Ringer

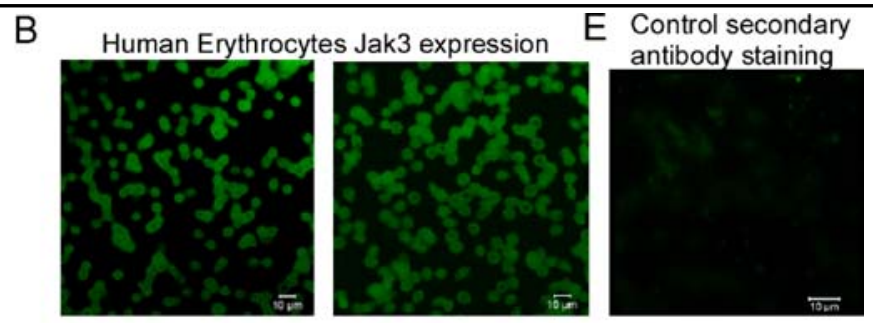

D
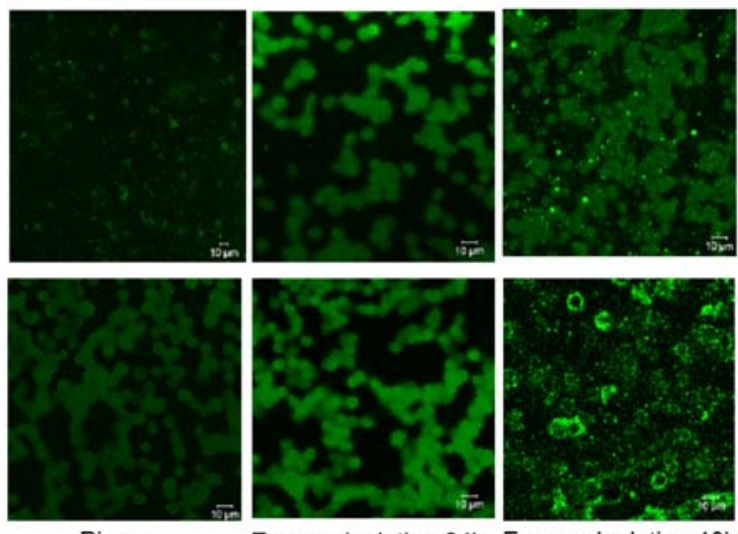

Energy depletion $24 \mathrm{~h}$ Energy depletion $48 \mathrm{~h}$

tibody. D. Confocal microscopy of FITC-dependent fluorescence of human erythrocytes stained with a primary anti-phospho${ }^{980}$ tyr-JAK3 antibody and a secondary FITC-conjugated anti rabbit antibody, erythrocytes were energy depleted by incubation in glucose-free Ringer for $24 \mathrm{~h}$ and $48 \mathrm{~h}$. E. Confocal microscopy of FITC-dependent fluorescence of human erythrocytes stained with the secondary rabbit antibody alone.

mounted with Prolong® Gold antifade reagent (Invitrogen). Images were taken on a Zeiss LSM 5 EXCITER Confocal Laser Scanning Microscope (Carl Zeiss MicroImaging GmbH, Germany) with a water immersion Plan-Neofluar 63/1.3 NA DIC.

\section{Incubations and solutions}

For the in vitro experiments on suicidal death of erythrocytes incubations were carried out at $37^{\circ} \mathrm{C}$ in Ringer solution at a hematocrit of $0.4 \%$ in a total volume of $200 \mu 1$. Where indicated, glucose-free Ringer was used. JAK3 inhibitors WHI-P131/JANEX-1 (4-(4'-Hydroxyphenyl)amino6,7-dimethoxyquinazoline, $156 \mu \mathrm{M})$ and WHI-P154 (4-[(3'Bromo-4'-hydroxyphenyl)amino]-6,7-dimethoxyquinazoline, $11.2 \mu \mathrm{M})$ and WHI-P97 $(22 \mu \mathrm{M})$ (all from Calbiochem, Bad Soden, Germany) were added to the respective solutions, where indicated.

\section{Determination of the osmotic resistance}

Two $\mu 1$ of blood were added to $200 \mu 1$ of PBS solutions with decreasing osmolarity. After centrifugation for $5 \mathrm{~min}$ at $500 \mathrm{x}$ g the supernatant was transferred to a 96 well plate and the absorption at $405 \mathrm{~nm}$ was determined as a measure of hemolysis. Absorption of the supernatant of erythrocytes lysed in pure distilled water was defined as $100 \%$ hemolysis.

Phosphatidylserine exposure and forward scatter

For FACS analysis erythrocytes were washed after incubation once in Ringer solution containing $5 \mathrm{mM} \mathrm{CaCl}_{2}$ [35].

JAK3 Activation Upon Energy Depletion
The cells were then stained with Annexin V-Fluos (Roche, Mannheim, Germany) at a 1:500 dilution. After $15 \mathrm{~min}$, samples were measured by flow cytometric analysis (FACSCalibur from Becton Dickinson; Heidelberg, Germany). Cells were analysed by forward scatter, and annexin V-fluorescence intensity was measured in fluorescence channel FL-1 with an excitation wavelength of $488 \mathrm{~nm}$ and an emission wavelength of $530 \mathrm{~nm}$.

\section{Measurement of intracellular ATP concentration}

For determination of erythrocyte ATP, $90 \mu 1$ of erythrocyte pellets were incubated for $48 \mathrm{~h}$ at $37^{\circ} \mathrm{C}$ in Ringer solution and glucose-free Ringer solution with or without addition of JAK3 inhibitors WHI-P131/JANEX-1 (4-(4'-Hydroxyphenyl)amino-6,7-dimethoxyquinazoline, $156 \mu \mathrm{M})$ and WHIP154 (4-[(3'-Bromo-4'-hydroxyphenyl)amino]-6,7-dimethoxyquinazoline, $11.2 \mu \mathrm{M}$ ) (final hematocrit $5 \%$ ). All manipulations were then performed at $4{ }^{\circ} \mathrm{C}$ to avoid ATP degradation. Cells were lysed in distilled water, and proteins were precipitated by addition of $\mathrm{HClO}_{4}(5 \%)$. After centrifugation, an aliquot of the supernatant $(400 \mu \mathrm{l})$ was adjusted to $\mathrm{pH} 7.7$ by addition of saturated $\mathrm{KHCO}_{3}$ solution. After dilution of the supernatant, the ATP concentrations of the aliquots were determined utilizing the luciferin-luciferase assay kit (Roche Diagnostics) on a luminometer (Berthold Biolumat LB9500, Bad Wildbad, Germany) according to the manufacturer's protocol. ATP concentrations are expressed in $\mathrm{mmol} / \mathrm{l}$ erythrocyte cytosol.

Cell Physiol Biochem 2011;27:547-556 


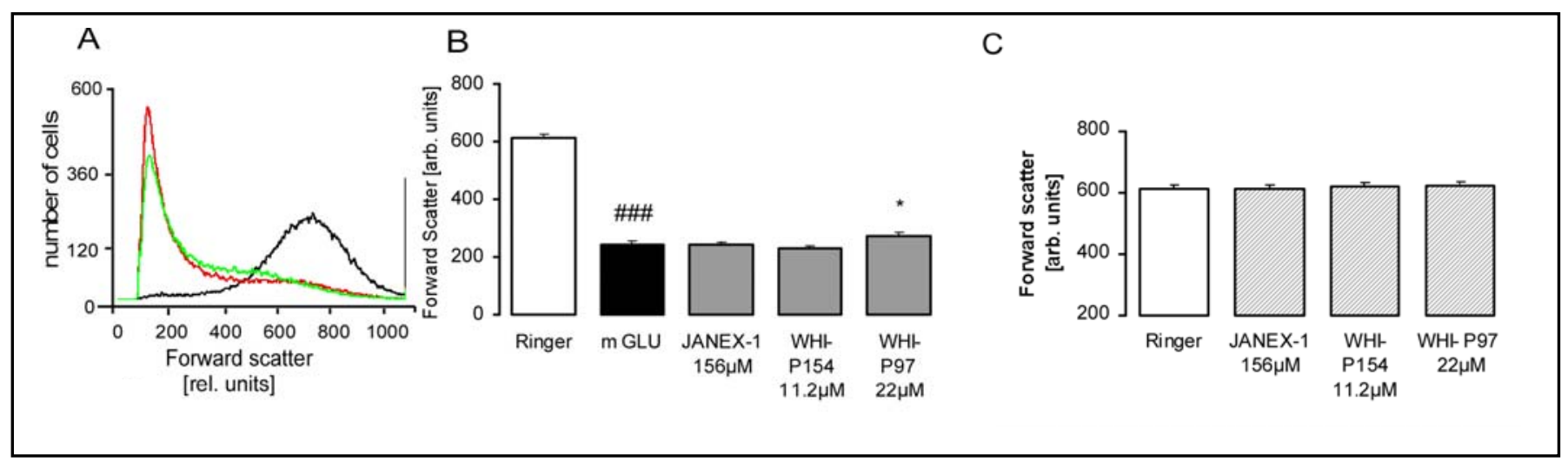

Fig. 2. Forward scatter with or without glucose depletion in the presence and absence of JAK3 inhibitors. A. Histogram of forward scatter in a representative experiment of erythrocytes exposed for $48 \mathrm{~h}$ to Ringer (1, black line), or glucose-depleted Ringer in the absence (2, red line) or presence (3, green line) of JAK3 inhibitor WHI-P131/JANEX-1 (156 $\mu \mathrm{M})$. B. Arithmetic means \pm SEM $(n=8)$ of the forward scatter of erythrocytes exposed for $48 \mathrm{~h}$ to glucose-containing Ringer without (open bars) or with (closed bars) WHI-P131/JANEX-1 $(156 \mu \mathrm{M})$ or WHI-P154 $(11.2 \mu \mathrm{M})$ or WHI-P97 $(22 \mu \mathrm{M})$. C. Arithmetic means \pm SEM (n=8) of the forward scatter of erythrocytes exposed for $48 \mathrm{~h}$ to glucose-containing ( + glu, left white bar) or glucose-depleted (mGLU $=$ minus glucose ringer), right bars) Ringer without (black bar) or with (grey bars) WHI-P131/JANEX-1 (156 $\mu \mathrm{M})$ or WHI-P154 (11.2 $\mu \mathrm{M})$. \#\#\# indicates significant $(\mathrm{p}<0.001)$ difference from glucose-containing Ringer, *indicates significant $(\mathrm{p}<0.05)$ difference from absence of JAK3 inhibitors (ANOVA).

\section{Statistics}

Data are expressed as arithmetic means \pm SEM and statistical analysis was made by paired or unpaired t-test, by U-test, or by ANOVA, as appropriate, $\mathrm{p}<0.05$ was considered as statistically significant.

\section{Results}

According to Western blotting, human erythrocytes express the JAK3 protein that is localized mainly in the cytoplasmic fraction (Fig. 1A). Confocal microscopy confirmed the expression of JAK3 in human erythrocytes (Fig. 1B), while staining of human erythrocytes with the secondary FITC-conjugated antibody without the primary antibody did not result in detectable fluorescence (Fig. 1E). According to confocal microscopy of immunofluorescence utilizing a phospho JAK3 (tyr 980) antibody a $24 \mathrm{~h}$ and $48 \mathrm{~h}$ glucose depletion increased the tyrosinephosphorylated JAK3 (Fig. 1D). JAK3 phosphorylation was further detected by immunoprecipitation with phospho-tyrosine antibody followed by immunoblotting with Jak3 antibody. The abundance of phospho-JAK3 was $122 \pm 15 \%(\mathrm{n}=4)$ higher in erythrocytes exposed for $24 \mathrm{~h}$ to glucose depleted Ringer than in erythrocytes exposed for $24 \mathrm{~h}$ to glucose containing Ringer (Fig. 1C).

Additional experiments were performed to determine, whether JAK3 is involved in the regulation of suicidal erythrocyte death or eryptosis following energy depletion. Hallmarks of eryptosis include cell shrinkage. Thus, forward scatter was employed to estimate alterations of cell volume. Glucose withdrawal (mGlu) indeed decreased forward scatter significantly (Fig. 2). The addition of WHI-P131/JANEX-1 $(156 \mu \mathrm{M})$ or WHIP154 $(11.2 \mu \mathrm{M})$ or WHI-P97 $(22 \mu \mathrm{M})$ did not significantly modify the forward scatter in the presence of glucose and did not significantly blunt the decrease of forward scatter following glucose depletion (Fig. 2).

Another hallmark of eryptosis is triggering of cell membrane scrambling resulting in exposure of phosphatidylserine at the erythrocyte surface. Phosphatidylserine exposing erythrocytes were identified by determination of annexin V-binding. Glucose withdrawal (mGlu) was followed by the expected significant increase in annexin V-binding (Fig. 3). Addition of WHI-P131/JANEX-1 $(156 \mu \mathrm{M})$ or WHI-P 154 $(11.2 \mu \mathrm{M})$ or WHI-P97 $(22 \mu \mathrm{M})$ did not significantly modify the percentage of annexin $\mathrm{V}$ binding erythrocytes in the presence of glucose but significantly blunted the increase of annexin $\mathrm{V}$ binding following glucose withdrawal (Fig. 3). A dose response curve for WHIP154 reveals maximal inhibition at a concentration of approximately $5 \mu \mathrm{M}$ (Fig. 3).

To determine, whether JAK 3 influences the decline of intracellular ATP concentration, cytosolic ATP was determined after $48 \mathrm{~h}$ incubation upon glucose withdrawal with or without presence of WHI-P131/JANEX-1 (156 $\mu \mathrm{M})$ or WHI-P154 (11.2 $\mu \mathrm{M})$. Energy depletion caused a significant reduction in intracellular ATP concentration 
Fig. 3. Annexin V binding with or without glucose depletion in the presence and absence of JAK3 inhibitors. A. Histogram of annexin $\mathrm{V}$ binding in a representative experiment of erythrocytes exposed for $48 \mathrm{~h}$ to Ringer (1, black line), or glucose-depleted Ringer in the absence ( 2 , red line) or presence (3, green line) of JAK3 inhibitor WHIP131/JANEX-1 $(156 \mu \mathrm{M}), \mathrm{M}$ is the marker indicating annexin positive cells. B. Arithmetic means \pm SEM $(n=8)$ of the percent Annexin $\mathrm{V}$ binding of erythrocytes exposed for $48 \mathrm{~h}$ to glucose-containing (+glu, left white bar) or glucose-depleted (mGLU, right bars) Ringer without (black bar) or with (grey bars) WHI-P131/JANEX-1 $(156 \mu \mathrm{M})$ or WHI-P154 $(11.2 \mu \mathrm{M})$ or WHI-P97 $(22 \mu \mathrm{M})$. \#\#\# indicates significant $(\mathrm{p}<0.001)$ difference from glucose-containing Ringer, *** $(\mathrm{p}<0.001), * *(\mathrm{p}<0.01), *(\mathrm{p}<0.05)$ indicates significant difference from the absence of
A

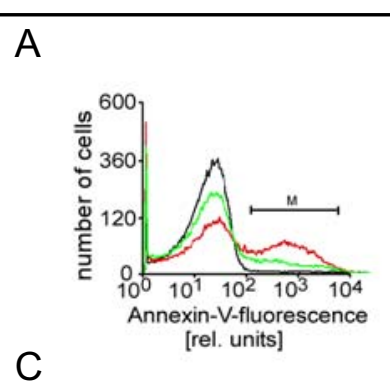

C

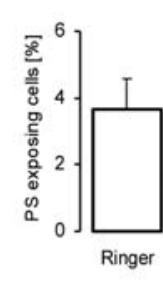

B
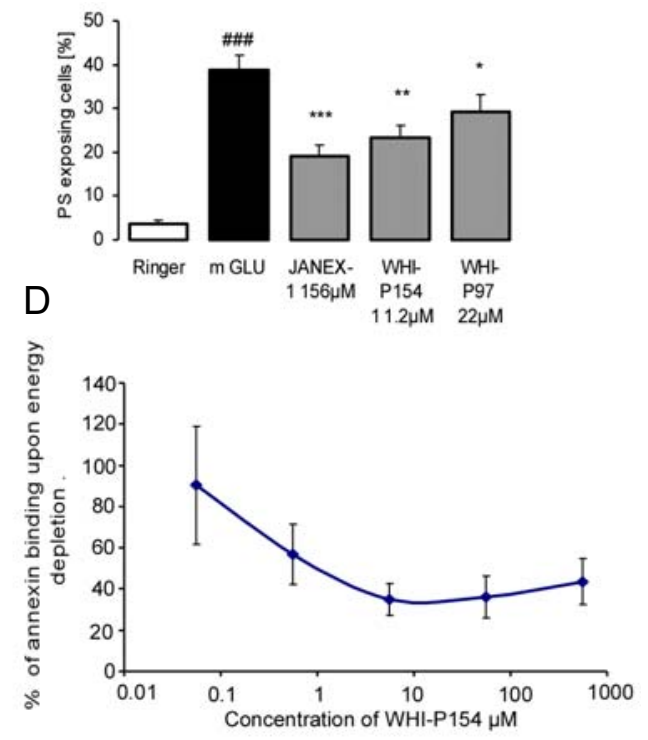

JAK3 inhibitors (ANOVA). C. Arithmetic means \pm SEM $(n=8)$ of the percent Annexin V binding of erythrocytes exposed for $48 \mathrm{~h}$ to glucose-containing Ringer without (open bars) or with (closed bars) WHI-P131/JANEX-1 (156 $\mu \mathrm{M})$, WHI-P154 (11.2 $\mu \mathrm{M})$ and WHI-P97 $(22 \mu \mathrm{M})$. D. Dose response curve of the antiscrambling effect of WHI-P154 during energy depletion. Arithmetic means $\pm \operatorname{SEM}(\mathrm{n}=3)$ of the $\%$ annexinV binding cells as a function of inhibitor concentration.

in erythrocytes. Addition of neither WHI-P131/JANEX$1(156 \mu \mathrm{M})$ nor WHI-P154 $(11.2 \mu \mathrm{M})$ significantly modified the effect of energy depletion on the intracellular ATP concentration (Fig. 4).

Further experiments were performed in gene targeted mice lacking functional JAK3 $\left(j a k 3^{--}\right)$and in the corresponding wild type mice $\left(j a k 3^{+/+}\right)$. Similar to human erythrocytes, wild type murine erythrocytes expressed JAK3 protein, while no band for JAK3 was detectable in western blot in erythrocytes from JAK3deficient mice $\left(\right.$ jak3 $\left.^{--}\right)$(Fig. 5A).

As shown in Fig. 5C, the reticulocyte number was not significantly different in jak3 $3^{-/}$mice than in $j a k 3^{+/+}$ mice. In addition, the plasma concentration of erythropoietin was also not different in $j a k 3^{-/}$mice than in $j a k 3^{+/+}$mice. The analysis of peripheral blood did not reveal any significant difference of red blood cell count (RBC), hematocrit (HCT), hemoglobin (HGB) concentration, mean corpuscular volume (MCV), mean corpuscular hemoglobin concentration (MCHC) and mean corpuscular hemoglobin $(\mathrm{MCH})$ between $j a k 3^{--}$ mice than in $j a k 3^{+/+}$mice (Fig. 5D). The osmotic resistance was also similar in both genotypes (Fig. 5E).

FACS analysis revealed that in the presence of glucose forward scatter was slightly but significantly smaller in $j a k 3^{-/-}$than in $j a k 3^{+/+}$erythrocytes (Fig. 6A and $6 \mathrm{~B}$ ), whereas annexin $\mathrm{V}$ binding was not significant

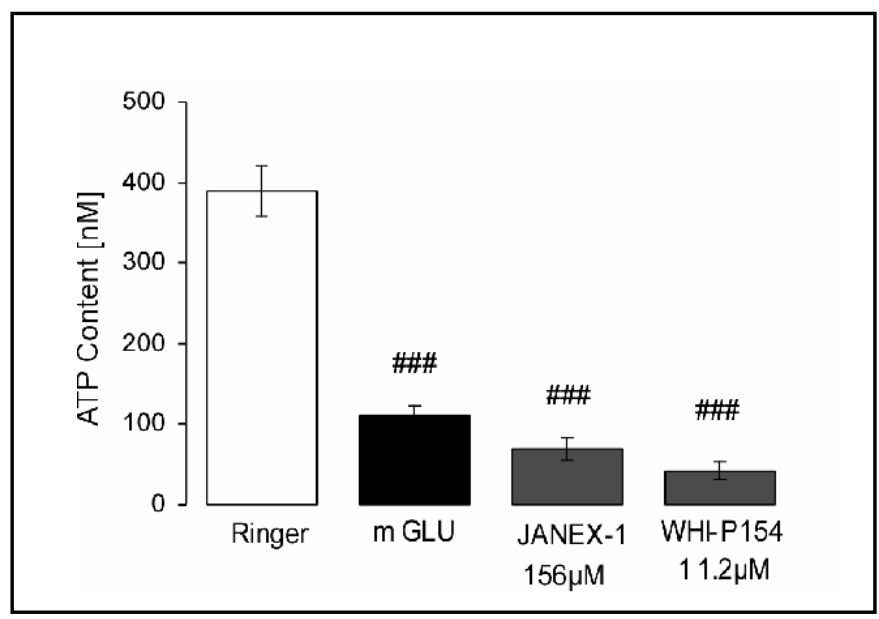

Fig. 4. Effect of glucose depletion on intracellular ATP content in the presence and absence of JAK3 inhibitors. Arithmetic means \pm SEM $(n=4)$ of the intracellular ATP content of erythrocytes exposed for $48 \mathrm{~h}$ to glucose-containing (Ringer, left white bar) or glucose-depleted (right bars) Ringer without (black bar) or with (grey bars) WHI-P131/JANEX-1 (156 $\mu \mathrm{M})$ and WHI-P154 $(11.2 \mu \mathrm{M})$. \#\#\# indicates significant $(\mathrm{p}<0.001)$ difference from glucose-containing Ringer.

different between $j a k 3^{-/-}$and $j a k 3^{+/+}$erythrocytes (Fig. 6C and 6D). To assess, whether genetic JAK3 deficiency modifies the eryptotic effect of energy depletion, jak $3^{-/-}$ and $j a k 3^{+/+}$erythrocytes were incubated for $16 \mathrm{~h}$ in the presence and absence of glucose. Energy-depletion 


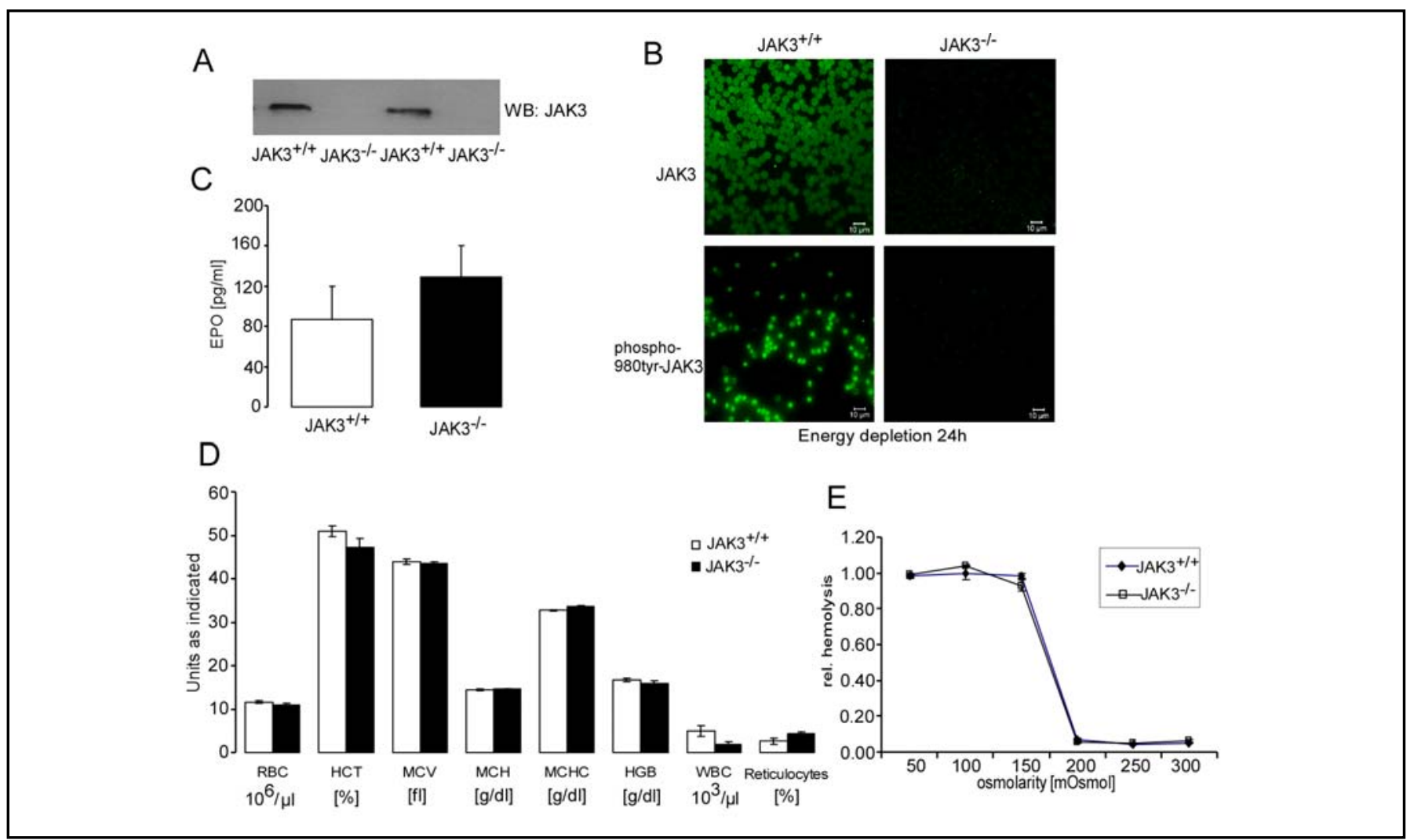

Fig. 5. Erythrocyte parameters in JAK3-deficient mice. A. Original Western blots demonstrating the expression of JAK3 protein in erythrocytes from two different JAK3-deficient mice (jak3 $3^{-/}$) and the corresponding wild type mice (jak $3^{+/+}$). B. Confocal microscopy of FITC-dependent fluorescence of murine erythrocytes from JAK3-deficient mice (jak $3^{-/}$) and corresponding wild type mice $\left(\mathrm{jak}^{+/+}\right)$stained with a primary anti-JAK3 antibody and a secondary FITC-conjugated anti rabbit antibody (upper panel) and stained with a primary anti-phospho- ${ }^{980}$ tyr-JAK3 antibody and a secondary FITC-conjugated anti rabbit antibody. Erythrocytes were energy depleted by incubation in zero glucose Ringer for $24 \mathrm{~h}$ (lower panel). C. Arithmetic means \pm SEM of the plasma erythropoietin concentration $(\mathrm{n}=4)$ of JAK3-deficient mice (jak3 ${ }^{-/}$, black bar) and the wild type mice (jak $3^{+/+}$, white bar). D. Arithmetic means $\pm \operatorname{SEM}(\mathrm{n}=4)$ of erythrocyte count $(\mathrm{RBC})$, hemoglobin concentration $(\mathrm{HGB})$, hematocrit (HCT), mean corpuscular volume $(\mathrm{MCV})$, mean corpuscular hemoglobin $(\mathrm{MCH})$, mean corpuscular hemoglobin concentration (MCHC), white blood cell count (WBC) and reticulocyte count of JAK3-deficient mice (jak3 ${ }^{-/}$, black bars) and the corresponding wild type mice (jak $3^{+/+}$, white bars). E. Osmotic resistance of erythrocytes from JAK3-deficient mice (jak3 ${ }^{-/}$, closed symbols) and the corresponding wild type mice $\left(\mathrm{jak}^{+/+}\right.$, open symbols).

resulted in cell shrinkage an effect not significantly different in $j a k 3^{-/}$and in $j a k 3^{+/+}$erythrocytes (Fig. 6A and 6B). Most importantly, glucose depletion was followed by an increase in annexin $\mathrm{V}$ binding, an effect significantly less pronounced in $j a k 3^{-/}$than in $j a k 3^{+/+}$erythrocytes (Fig. 6C and 6D).

As the inhibitors are not specific [36], we performed additional experiments to elucidate whether the antiscrambling effect of the inhibitors was related to their effect on Jak3. To this end, we evaluated the effect of the inhibitor WHI-P131/JANEX-1 $(156 \mu \mathrm{M})$ in jak3-and $j a k 3^{+/+}$erythrocytes upon energy depletion. As a result, the inhibitor significantly blunted the annexin $\mathrm{V}$ binding in glucose depleted $j a k 3^{+/+}$erythrocytes but did not significantly modify annexin $\mathrm{V}$ binding in energy depleted jak3 $3^{-/}$erythrocytes (Fig. 6E). WHI-P154 tended to decrease annexin $\mathrm{V}$ binding in glucose depleted $j a k 3^{+/+}$erythrocytes but not in energy depleted jak $3^{-/-}$ erythrocytes (Fig. 6E). For both substances the inhibitory effect was significantly less pronounced in $j a k 3^{-/-}$than in $\mathrm{jak3}^{+/+}$erythrocytes. Accordingly, WHI-P131/JANEX1 and presumably WHI-P154 inhibits eryptosis at least partially by inhibiting Jak3.

\section{Discussion}

The present observations disclose a completely novel role of Janus kinase 3 JAK3. They demonstrate for the first time expression of JAK3 in erythrocytes. Moreover, they reveal that JAK 3 is phosphorylated upon energy depletion. The antibody used detects phosphorylation at 
Fig. 6. Decreased eryptosis of energy depleted erythrocytes from JAK3-deficient mice. A. Histogram of forward scatter as a measure of cell volume in a representative experiment of erythrocytes from JAK3-deficient mice $\left(\mathrm{jak}^{-/-}\right)$(green line) and the corresponding wild mice $\left(\mathrm{jak}^{+/+}\right)$(black line) exposed for $16 \mathrm{~h}$ to glucose-depleted Ringer. B. Arithmetic means \pm SEM $(n=4)$ of forward scatter of erythrocytes from JAK3deficient mice (jak3 ${ }^{--}$, black bars) and the corresponding wild type mice (jak3 ${ }^{+/+}$, white bars) spontaneous cell size at the beginning of the incubation (left bars) or exposed for $16 \mathrm{~h}$ to glucose-depleted Ringer (right bars). $* *$ indicates significant difference $(p<0.05)$ from wild type mice (ANOVA). C. Histogram of annexin Vbinding reflecting phosphatidylserine exposure in a representative experiment of erythrocytes from JAK3deficient mice $\left(\mathrm{jak}^{-/ /}\right)$(green line) and the corresponding wild type mice $\left(\mathrm{jak}^{+/+}\right.$) (black line) exposed for $16 \mathrm{~h}$ to glucose-depleted Ringer. D. Arithmetic means \pm SEM $(n=4)$ of the percentage of annexin V-binding erythrocytes from JAK3-deficient mice (jak3 ${ }^{-/}$, black bars) and the corresponding wild type mice $\left(\mathrm{jak} 3^{+/+}\right.$, white bars) prior to (left bars) or following (right bars) exposure for $16 \mathrm{~h}$ to glucose-depleted Ringer. \#\#\# indicates significant $(\mathrm{p}<0.001)$ difference from spontaneous annexin $\mathrm{V}$-binding, $* * *$ indicates significant $(\mathrm{p}<0.001)$ difference from wild type mice (ANOVA). E. Arithmetic means \pm SEM $(n=4)$ of the percentage of annexin V-binding erythrocytes from JAK3-deficient mice (jak3 $3^{-/}$, black bars) and the corresponding wild type mice (jak $3^{+/+}$, white bars) exposed for $16 \mathrm{~h}$ to glucose-depleted Ringer in the presence or absence of Jak3 inhibitor WHI-P131/JANEX-1 $(156 \mu \mathrm{M})$ or WHIP154 $(11.2 \mu \mathrm{M}) . * *$ indicates significant $(\mathrm{p}<0.05)$ difference from the absence of JAK3 inhibitors.

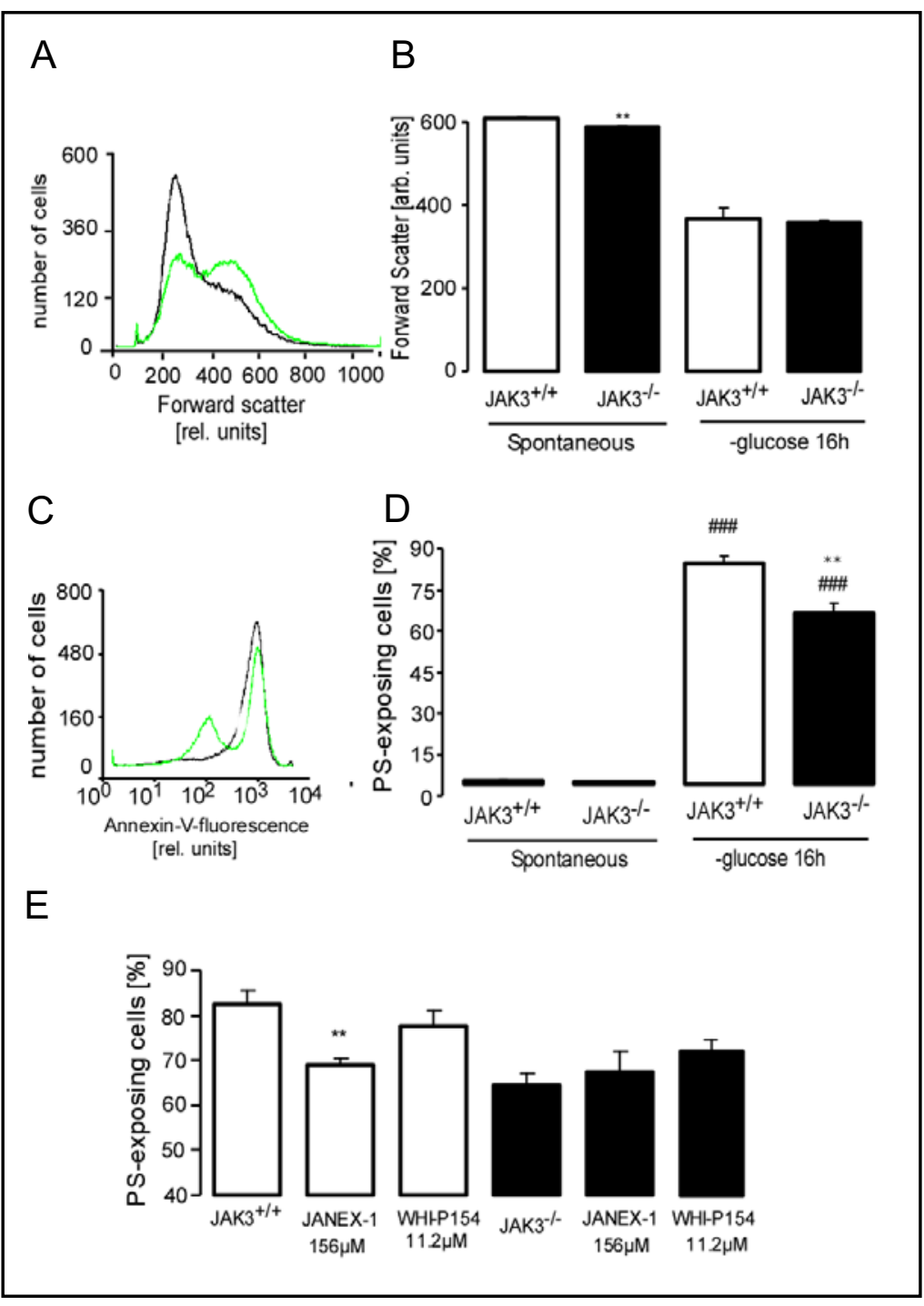

Inhibition of JAK 3 in human erythrocytes and genetic knockout of JAK3 do not appreciably modify cell membrane scrambling of unstressed erythrocytes. Presumably the kinase is largely inactive and does not play a major role in the absence of cell stress. Nevertheless, the erythrocyte volume appears to be slightly smaller in gene targeted mice lacking functional JAK3 $\left(j a k 3^{--}\right)$than in the corresponding wild type mice $\left(j a k 3^{+++}\right)$JAK3 is apparently activated upon energy depletion and contributes to the stimulation of cell membrane scrambling in energy depleted erythrocytes. The effect of pharmacological or genetic knockout is, however, modest, indicating that other, JAK independent, mechanisms participate in the triggering of eryptosis during energy depletion. As demonstrated earlier [31], energy depletion by glucose withdrawal stimulates protein kinase $\mathrm{C}$ and leads to increase of cytosolic $\mathrm{Ca}^{2+}$ concentration in erythrocytes. The cellular energy

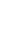


status is further sensed by the AMP-activated protein kinase (AMPK), which is activated upon increase in cytosolic AMP/ATP concentration ratio [38, 39], an increase in cytosolic $\mathrm{Ca}^{2+}$ concentration [38] and by nitric oxide [40]. AMPK stimulates cellular glucose uptake, glycolysis, stimulation of fatty acid oxidation and expression of enzymes required for ATP production [39, 41-43]. The kinase downregulates energy-utilizing mechanisms including protein synthesis, gluconeogenesis and lipogenesis [39, 41, 44]. Thus, AMPK enhances the capacity of the cell to generate ATP [44] and to survive energy depletion $[44,45]$. In analogy to its antiapoptotic effect in nucleated cells [45], AMPK protects against the suicidal erythrocyte death [32]. At least in theory, AMPK could contribute to the powerful inhibitory effect of $\mathrm{NO}$ on $\mathrm{Ca}^{2+-}$ induced cell membrane scrambling of erythrocytes [46]. Even though it is similarly activated by energy depletion, JAK 3 does not protect against but stimulates erythrocyte death.

The effect of glucose depletion and its sensitivity to JAK3 is qualitatively similar but not quantitatively identical in human and murine erythrocytes. The murine erythrocytes are obviously more sensitive to glucose depletion. Murine erythrocytes further appear to be less sensitive to the JAK3 inhibitors than human erythrocytes. In both species, however, JAK3 fosters cell membrane scrambling.

JAK3-sensitive erythrocyte survival may be relevant for the life span of circulating erythrocytes. Phosphatidylserine-exposing cells are bound to [47] and subsequently engulfed by [48] macrophages. They are thus rapidly cleared from circulating blood [22]. Accordingly, accelerated eryptosis may lead to anemia [12]. However, as indicated above, in energy replete conditions JAK 3 does not appreciably modify eryptosis. Along those lines, the blood count is not significantly different between $j a k 3^{-/}$mice and $j a k 3^{+/+}$mice. The difference between $j a k 3^{--}$mice and $j a k 3^{+/+}$mice may become only apparent under conditions of energy depletion.

Eryptosis may further affect the microcirculation. Phosphatidylserine-exposing erythrocytes may bind to the vascular wall [49-53] and foster the assembly of prothrombinase and tenase, the generation of thrombin and thus blood clotting $[49,54,55]$. For instance, enhanced trapping of eryptotic erythrocytes has previously been observed in renal medulla following ischemia [56]. Accordingly, suicidal erythrocytes have thus been proposed to participate in vascular injury of metabolic syndrome [57]. An influence of JAK3 on adhesion to the vascular wall is, however, only expected during energy deleption of circulating erythrocytes.

In view of the present observations, JAK3 may be similarly activated upon energy depletion of nucleated cells. Energy dependent JAK3 activity may have significant implications in the development and progression of tumors, as activating JAK3 mutations have been linked to the development of human lymphoid cancer cells [58$60]$ as well as the development and progression of solid tumors [61, 62].

In conclusion, the present observations reveal that erythrocytes express JAK3, which is activated by and participates in the cell membrane scrambling effect of energy depletion. The present observations thus reveal a novel regulator of eryptosis and a novel regulation and function of JAK3.

\section{Acknowledgements}

The authors acknowledge meticulous preparation of the manuscript by Tanja Loch and Sari Rübe. This study was supported by the Deutsche Forschungsgemeinschaft, GRK 1302, SFB 773, La 315/13-3. Contract grant sponsor: Deutsche Forschungsgesellschaft (DFG). Contract grant numbers: GRK 1302, SFB 773, La 315/13-3.

\section{References}

Cornejo MG, Boggon TJ, Mercher T: JAK3: a two-faced player in hematological disorders. Int J Biochem $>4$ Cell Biol 2009;41:2376-2379.

Ghoreschi K, Laurence A, O'Shea JJ: Janus kinases in immune cell signaling. Immunol Rev 2009;228:273-287.
Imada K, Leonard WJ: The Jak-STAT 6 pathway. Mol Immunol 2000;37:1-11.

O'Shea JJ, Gadina M, Schreiber RD: Cytokine signaling in 2002: new surprises in the Jak/Stat pathway. Cell 2002;109 Suppl:S121-S131.

Shuai K, Liu B: Regulation of JAK-STAT signalling in the immune system. Nat Rev Immunol 2003;3:900-911. de Totero D, Meazza R, Capaia M, Fabbi M, Azzarone B, Balleari E, Gobbi M, Cutrona G, Ferrarini M, Ferrini S: The opposite effects of IL-15 and IL-21 on CLL B cells correlate with differential activation of the JAK/STAT and ERK1/ 2 pathways. Blood 2008;111:517-524. 
7 Fainstein N, Vaknin I, Einstein O, Zisman P, Ben Sasson SZ, Baniyash M, Ben Hur T: Neural precursor cells inhibit multiple inflammatory signals. Mol Cell Neurosci 2008;39:335-341

$\checkmark 8$ Nakayama J, Yamamoto M, Hayashi K, Satoh H, Bundo K, Kubo M, Goitsuka R, Farrar MA, Kitamura D: BLNK suppresses pre-B-cell leukemogenesis through inhibition of JAK3. Blood 2009;113:1483-1492.

9 Kim BH, Oh SR, Yin CH, Lee S, Kim EA, Kim MS, Sandoval C, Jayabose S, Bach EA, Lee HK, Baeg GH: MS-1020 is a novel small molecule that selectively inhibits JAK3 activity. Br J Haematol 2009; in press.

-10 Uckun FM, Vassilev A, Dibirdik I, Tibbles $\mathrm{H}$ : Targeting JAK3 tyrosine kinase-linked signal transduction pathways with rationally-designed inhibitors. Anticancer Agents Med Chem 2007;7:612-623.

-11 Yamaoka K, Min B, Zhou YJ, Paul WE, O'Shea JJ: Jak3 negatively regulates dendritic-cell cytokine production and survival. Blood 2005;106:3227-3233.

$\$ 12$ Lang F, Gulbins E, Lerche H, Huber SM, Kempe DS, Foller M: Eryptosis, a window to systemic disease. Cell Physiol Biochem 2008;22:373-380.

$\checkmark 13$ Foller M, Bobbala D, Koka S, Huber SM, Gulbins E, Lang F: Suicide for survivaldeath of infected erythrocytes as a host mechanism to survive malaria. Cell Physiol Biochem 2009;24:133-140.

$\checkmark 14$ Lang F, Gulbins E, Lang PA, Zappulla D, Foller M: Ceramide in suicidal death of erythrocytes. Cell Physiol Biochem 2010;26:21-28.

-15 Braun M, Foller M, Gulbins E, Lang F: Eryptosis triggered by bismuth. Biometals 2009;22:453-460.

-16 Mahmud H, Foller M, Lang F: Arsenicinduced suicidal erythrocyte death. Arch Toxicol 2009;83:107-113.

$\checkmark 17$ Mahmud H, Mauro D, Foller M, Lang F: Inhibitory effect of thymol on suicidal erythrocyte death. Cell Physiol Biochem 2009;24:407-414.

$\checkmark 18$ Mahmud H, Mauro D, Qadri SM, Foller M, Lang F: Triggering of suicidal erythrocyte death by amphotericin B. Cell Physiol Biochem 2009;24:263-270.

19 Bhavsar SK, Bobbala D, Xuan NT, Foller M, Lang F: Stimulation of suicidal erythrocyte death by alpha-lipoic acid. Cell Physiol Biochem 2010;26:859-868.

-20 Bhavsar SK, Eberhard M, Bobbala D, Lang F: Monensin induced suicidal erythrocyte death. Cell Physiol Biochem 2010;25:745-752.

-21 Eberhard M, Ferlinz K, Alizzi K, Cacciato PM, Faggio C, Foller M, Lang F: FTY720-induced suicidal erythrocyte death. Cell Physiol Biochem 2010;26:761-766.
22 Kempe DS, Lang PA, Duranton C, Akel A, Lang KS, Huber SM, Wieder T, Lang F: Enhanced programmed cell death of iron-deficient erythrocytes. FASEB J 2006;20:368-370.

Birka C, Lang PA, Kempe DS, Hoefling L, Tanneur V, Duranton C, Nammi S, Henke G, Myssina S, Krikov M, Huber SM, Wieder T, Lang F: Enhanced susceptibility to erythrocyte "apoptosis" following phosphate depletion. Pflugers Arch 2004;448:471-477.

Lang PA, Beringer O, Nicolay JP, Amon O, Kempe DS, Hermle T, Attanasio P Akel A, Schafer R, Friedrich B, Risler T, Baur M, Olbricht CJ, Zimmerhackl LB, Zipfel PF, Wieder T, Lang F: Suicidal death of erythrocytes in recurrent hemolytic uremic syndrome. J Mol Med 2006;84:378-388.

Kempe DS, Akel A, Lang PA, Hermle T, Biswas R, Muresanu J, Friedrich B, Dreischer P, Wolz C, Schumacher U, Peschel A, Gotz F, Doring G, Wieder T, Gulbins E, Lang F: Suicidal erythrocyte death in sepsis. J Mol Med 2007;85:269 277.

Lang PA, Kasinathan RS, Brand VB Duranton C, Lang C, Koka S, Shumilina E, Kempe DS, Tanneur V, Akel A, Lang KS, Foller M, Kun JF, Kremsner PG, Wesselborg S, Laufer S, Clemen CS, Herr C, Noegel AA, Wieder T, Gulbins E, Lang F, Huber SM: Accelerated clearance of Plasmodium-infected erythrocytes in sickle cell trait and annexin-A7 deficiency. Cell Physiol Biochem 2009;24:415-428.

27 Koka S, Bobbala D, Lang C, Boini KM, Huber SM, Lang F: Influence of paclitaxel on parasitemia and survival of Plasmodium berghei infected mice. Cell Physiol Biochem 2009;23:191-198.

Bobbala D, Alesutan I, Foller M, Huber SM, Lang F: Effect of anandamide in Plasmodium Berghei-infected mice. Cell Physiol Biochem 2010;26:355-362. Siraskar B, Ballal A, Bobbala D, Foller M, Lang F: Effect of amphotericin B on parasitemia and survival of plasmodium berghei-infected mice. Cell Physiol Biochem 2010;26:347-354.

Lang PA, Schenck M, Nicolay JP, Becker JU, Kempe DS, Lupescu A, Koka S, Eisele K, Klarl BA, Rubben H, Schmid KW, Mann K, Hildenbrand S, Hefter H, Huber SM, Wieder T, Erhardt A, Haussinger D, Gulbins E, Lang F: Liver cell death and anemia in Wilson disease involve acid sphingomyelinase and ceramide. Nat Med 2007;13:164-170.

Klarl BA, Lang PA, Kempe DS, Niemoeller OM, Akel A, Sobiesiak M, Eisele K, Podolski M, Huber SM, Wieder $\mathrm{T}$, Lang F: Protein kinase $\mathrm{C}$ mediates erythrocyte "programmed cell death" following glucose depletion. Am J Physiol Cell Physiol 2006;290:C244-C253.
Foller M, Sopjani M, Koka S, Gu S, Mahmud H, Wang K, Floride E, Schleicher E, Schulz E, Munzel T, Lang F: Regulation of erythrocyte survival by AMP-activated protein kinase. FASEB J 2009;23:1072-1080.

$\$ 33$ Foller M, Mahmud H, Gu S, Wang K, Floride E, Kucherenko Y, Luik S, Laufer S, Lang F: Participation of leukotriene $\mathrm{C}(4)$ in the regulation of suicidal erythrocyte death. J Physiol Pharmacol 2009; 60:135-143.

Thomis DC, Lee W, Berg LJ: T cells from Jak3-deficient mice have intact TCR signaling, but increased apoptosis. J Immunol 1997;159:4708-4719.

Foller M, Shumilina E, Lam R, Mohamed W, Kasinathan R, Huber S, Chakraborty $\mathrm{T}$, Lang F: Induction of suicidal erythrocyte death by listeriolysin from Listeria monocytogenes. Cell Physiol Biochem 2007;20:1051-1060.

$>36$ Linwong W, Hirasawa N, Aoyama S, Hamada H, Saito T, Ohuchi K: Inhibition of the antigen-induced activation of rodent mast cells by putative Janus kinase 3 inhibitors WHI-P131 and WHIP154 in a Janus kinase 3-independent manner. Br J Pharmacol 2005;145:818828 .

37 Zhou YJ, Hanson EP, Chen YQ, Magnuson K, Chen M, Swann PG, Wange RL, Changelian PS, O'Shea JJ: Distinct tyrosine phosphorylation sites in JAK3 kinase domain positively and negatively regulate its enzymatic activity. Proc Nat Acad Sci U S A 1997;94:13850-13855. Towler MC, Hardie DG: AMP-activated protein kinase in metabolic control and insulin signaling. Circ Res 2007;100:328 341 .

Winder WW, Thomson DM: Cellular energy sensing and signaling by AMPactivated protein kinase. Cell Biochem Biophys 2007;47:332-347.

$\$ 40$ Lira VA, Soltow QA, Long JH, Betters JL, Sellman JE, Criswell DS: Nitric oxide increases GLUT4 expression and regulates AMPK signaling in skeletal muscle. Am J Physiol Endocrinol Metab 2007;293:E1062-E1068.

Carling D: The role of the AMP-activated protein kinase in the regulation of energy homeostasis. Novartis Found Symp 2007;286:72-81

42 Horie T, Ono K, Nagao K, Nishi H, Kinoshita M, Kawamura T, Wada H, Shimatsu A, Kita T, Hasegawa K: Oxidative stress induces GLUT4 translocation by activation of PI3-K/Akt and dual AMPK kinase in cardiac myocytes. J Cell Physiol 2008;215:733-742.

$\$ 4$ Jensen TE, Rose AJ, Hellsten Y, Wojtaszewski JF, Richter EA: Caffeineinduced $\mathrm{Ca}\left({ }^{2+}\right)$ release increases AMPKdependent glucose uptake in rodent soleus muscle. Am J Physiol Endocrinol Metab 2007;293:E286-E292. 
$\$ 44$ McGee SL, Hargreaves M: AMPK and transcriptional regulation. Front Biosci 2008; 13:3022-3033.

45 Hardie DG: The AMP-activated protein kinase pathway-new players upstream and downstream. J Cell Sci 2004;117:5479-5487.

$>46$ Nicolay JP, Gatz S, Liebig G, Gulbins E, Lang F: Amyloid induced suicidal erythrocyte death. Cell Physiol Biochem 2007;19:175-184.

-47 Fadok VA, Bratton DL, Rose DM, Pearson A, Ezekewitz RA, Henson PM A receptor for phosphatidylserine-specific clearance of apoptotic cells. Nature 2000;405:85-90.

$\checkmark 48$ Boas FE, Forman L, Beutler E: Phosphatidylserine exposure and red cell viability in red cell aging and in hemolytic anemia. Proc Natl Acad Sci USA 1998;95:3077-3081.

$\checkmark 49$ Andrews DA, Low PS: Role of red blood cells in thrombosis. Curr Opin Hematol 1999;6:76-82.

$\checkmark 50$ Closse C, Dachary-Prigent J, Boisseau MR: Phosphatidylserine-related adhesion of human erythrocytes to vascular endothelium. Br J Haematol 1999;107:300302 .

-51 Gallagher PG, Chang SH, Rettig MP, Neely JE, Hillery CA, Smith BD, Low PS: Altered erythrocyte endothelial adherence and membrane phospholipid asymmetry in hereditary hydrocytosis. Blood 2003;101:4625-4627.
52 Pandolfi A, Di Pietro N, Sirolli V, Giardinelli A, Di Silvestre S, Amoroso L, Di Tomo P, Capani F, Consoli A, Bonomini M: Mechanisms of uremic erythrocyte-induced adhesion of human monocytes to cultured endothelial cells. J Cell Physiol 2007;213:699-709.

Wood BL, Gibson DF, Tait JF: Increased erythrocyte phosphatidylserine exposure in sickle cell disease: flow-cytometric measurement and clinical associations. Blood 1996;88:1873-1880.

54 Chung SM, Bae ON, Lim KM, Noh JY, Lee MY, Jung YS, Chung JH: Lysophosphatidic acid induces thrombogenic activity through phosphatidylserine exposure and procoagulant microvesicle generation in human erythrocytes. Arterioscler Thromb Vasc Biol 2007;27:414-421.

55 Zwaal RF, Comfurius P, Bevers EM: Surface exposure of phosphatidylserine in pathological cells. Cell Mol Life Sci 2005;62:971-988.

\$5 Lang KS, Myssina S, Lang PA, Tanneur V, Kempe DS, Mack AF, Huber SM, Wieder T, Lang F, Duranton C: Inhibition of erythrocyte phosphatidylserine exposure by urea and $\mathrm{Cl}^{-}$. Am J Physiol Renal Physiol 2004;286:F1046-F1053. Zappulla D: Environmental stress, erythrocyte dysfunctions, inflammation, and the metabolic syndrome: adaptations to $\mathrm{CO}_{2}$ increases? J Cardiometab Syndr 2008;3:30-34
Kiyoi H, Yamaji S, Kojima S, Naoe T: JAK3 mutations occur in acute megakaryoblastic leukemia both in Down syndrome children and non-Down syndrome adults. Leukemia 2007;21:574576.

59 Lai R, Rassidakis GZ, Lin Q, Atwell C, Medeiros LJ, Amin HM: Jak3 activation is significantly associated with ALK expression in anaplastic large cell lymphoma. Hum Pathol 2005;36:939-944.

-60 Nagy ZS, Ross JA, Rodriguez G, Bader J, Dimmock J, Kirken RA: Uncoupling JAK3 activation induces apoptosis in human lymphoid cancer cells via regulating critical survival pathways. FEBS Lett 2010;584:1515-1520.

-61 Al Rawi MA, Mansel RE, Jiang WG: Interleukin-7 (IL-7) and IL-7 receptor (IL-7R) signalling complex in human solid tumours. Histol Histopathol 2003;18:911-923.

62 Rocha-Zavaleta L, Huitron C, CaceresCortes JR, Alvarado-Moreno JA, ValleMendiola A, Soto-Cruz I, Weiss-Steider B, Rangel-Corona R: Interleukin-2 (IL2) receptor-betagamma signalling is activated by c-Kit in the absence of IL-2, or by exogenous IL-2 via JAK3/STAT5 in human papillomavirus-associated cervical cancer. Cell Signal 2004;16:12391247. 